\title{
Climate change impacts on stand structure and competitive interactions in a southern Swedish spruce-beech forest
}

\author{
Andreas Bolte $\cdot$ Lutz Hilbrig $\cdot$ Britt Grundmann • \\ Friederike Kampf · Jörg Brunet · Andreas Roloff
}

Received: 24 March 2009/Revised: 16 July 2009/Accepted: 21 September 2009/Published online: 14 November 2009

(C) The Author(s) 2009. This article is published with open access at Springerlink.com

\begin{abstract}
It is believed that European beech (Fagus sylvatica L.) will increase its competitive ability at its northern range margin in Scandinavia due to climate change. In mixed old-growth forests of beech and Norway spruce (Picea abies (L.) Karst.) at Siggaboda nature reserve (southern Sweden), stand structure characteristics were sequentially recorded in the years 2004, 2005 and 2007 as well as growth in stem diameter using tree-coring analyses. Using these measurements, we studied the effects on stand dynamics of an extreme storm event (2005 "Gudrun" hurricane), drought and heat (mid-summer 2006, spring 2007) and subsequent bark beetle attacks on spruce (growing season 2007), overlaid with warming
\end{abstract}

Communicated by C. Ammer.

A. Bolte $(\bowtie) \cdot$ L. Hilbrig

Institute of Forest Ecology and Forest Inventory, Johann Heinrich von Thünen-Institute (vTI), Federal Research Institute for Rural Areas, Forestry and Fisheries, A.-Möller-Straße 1, 16225 Eberswalde, Germany

e-mail: andreas.bolte@vti.bund.de

A. Bolte · F. Kampf

Department of Silviculture and Forest Ecology of the Temperate Zones, Georg-August-University Göttingen, Büsgenweg 1,

37077 Göttingen, Germany

B. Grundmann · A. Roloff

Institute of Forest Botany and Forest Zoology, Technical

University of Dresden (TUD), Pienner Straße 7, 01737 Tharandt,

Germany

J. Brunet

Southern Swedish Forest Research Centre, Swedish University of Agricultural Sciences (SLU), P.O. Box 49, 23053 Alnarp, Sweden tendencies. The storm, which caused disastrous damage in many stands nearby, had comparatively little impact on the structure of the spruce-beech stand. All together, only 32 trees (19 spruces, 10 beeches, 3 other species) per hectare were thrown or broken mainly in the leeward direction (NE) or impacted by secondary damage by uprooted neighbour trees; this represents $7 \%$ of the total tree number and $11 \%$ of the growing stock. Diameter and height structure did not change significantly. However, the 2006 drought and the 2007 attack of biotic agents changed the stand structure and composition strongly due to the death of about $19 \%$ of the dominating older spruce trees that accounted for $35 \%$ of total stand volume. This resulted in a considerable increase in beech's contribution to stem number (4\% increase) and wood volume of the living stand (7\% increase). A comparison of diameter growth of beech and spruce during the periods 1894-1949 and 1950-2005 showed a distinct decrease in growth superiority of spruce during the last 50 years. These results support the idea of a northward migration of European beech as a nemoral tree species in Sweden, due to a higher tolerance to the abiotic and biotic threats accompanying climate change and an increased competitive ability compared to boreal tree species Norway spruce.

Keywords Fagus sylvatica - Picea abies - Natural forest . Disturbance $\cdot$ Storm · Drought - Bark beetle . Interspecific competition - Competition index . Stand structure $\cdot$ Tree ring analysis

\section{Introduction}

Today, European beech (Fagus sylvatica L.) seems to be a markedly successful tree species in the centre of its 
distribution range (Leuschner et al. 2006); its range in north-eastern Europe is believed to be larger than its estimated original distribution (Giesecke et al. 2007; Bolte et al. 2007). At the northern margin of beech's range in southern Sweden, mean annual air temperature has risen about $1{ }^{\circ} \mathrm{C}$ during the past 100 years and is projected to increase by a further $2-6^{\circ} \mathrm{C}$ by the end of this century due to climate change (Christensen and Christensen 2007). The likely extended growing season and a precipitation decrease of up to $40 \%$ (Christensen et al. 2007) may favour the competitive ability of European beech compared to the currently dominant Norway spruce (Picea abies (L.) Karst.) (Bolte et al. 2009). With regard to future storm impacts, there are several coherent model simulation outputs that point to a slight increase (with a high degree of uncertainty) in the frequency of extreme storms in Europe (Leckebusch and Ulbrich 2004; Fuhrer et al. 2006). Occurrences of extreme wind intensity are also expected to increase (Leckebusch et al. 2006) with a focus in northwestern Europe, including southern Scandinavia. Under these future conditions, the performance of Norway spruce may be reduced compared to beech, due to its higher susceptibility to wind throw (e.g. Schlyter et al. 2006). Moreover, warming and increased drought and storm risks are accompanied by additional biotic threats due to changed pathogen and pest regimes (Jönsson et al. 2007). Timber losses due to bark beetle infestations in European coniferous forests (including Norway spruce) have already increased in the recent past (Schelhaas et al. 2003; Dobbertin and DeVries 2008).

Thus, climate change may alter not only growth, survival and reproduction conditions, but also the distribution, extent, frequency and/or intensity of discrete disturbance events. These disturbances will have strong impacts on forests as a whole (Dale et al. 2001) and on the competitive interactions of tree species within forest ecosystems.

The present study was conducted in a semi-natural oldgrowth spruce-beech forest in Småland (southern Sweden). From 2004 onwards, the stand suffered three extreme abiotic and biotic disturbance events, all of which are thought to increase in frequency and/or intensity due to climate change (Schlyter et al. 2006). These events comprised the 'Gudrun' hurricane in January 2005, a midsummer drought and heat wave in 2006 and a bark beetle attack during 2007. The specific objectives of this study were (1) to analyse the impacts of the different disturbance events on the stand structure, (2) to compare warming and disturbance effects on spruce and beech trees and (3) to evaluate potential changes in the interspecific competitive abilities of mixed spruce and beech.

\section{Materials and methods}

Study site and stand characteristics

The study area is located at Siggaboda nature reserve (70 ha) in southern Småland $\left(56^{\circ} 27^{\prime} \mathrm{N} ; 14^{\circ} 33^{\prime} \mathrm{E}\right)$, at the southern margin of the boreo-nemoral zone (Sjörs 1999). It is part of the Småland's forest and lake district and situated $140 \mathrm{~m}$ to $165 \mathrm{~m}$ a.s.l on a plateau criss-crossed with small boulder ridges (Fig. 1). The moss-covered boulders, measuring up to $5 \mathrm{~m}$ in diameter, are a significant feature of the reserve, along with the rare invertebrate fauna and epiphytic lichen flora (Nilsson et al. 1995).

Mean annual temperature is $6^{\circ} \mathrm{C}$, whilst during the growing season (May to September) the mean temperature is $12^{\circ} \mathrm{C}$. Mean temperature varies from $-3^{\circ} \mathrm{C}$ in January to $15^{\circ} \mathrm{C}$ in July; annual precipitation is $700 \mathrm{~mm} \mathrm{year}^{-1}$ (Raab and Vedin 1995).

Soil has developed from granitic gneiss bedrock covered with moraine sediments. Fine soil material is dominated by silt $(40-50 \%)$ and sand $(33-52 \%)$; the clay proportion is relatively low $(8-17 \%)$. Organic material has accumulated to a thick organic layer of $10-12 \mathrm{~cm}$; thus, humus type is raw humus with a high $\mathrm{C} / \mathrm{N}$ ratio. Soil type is a Cambic Podzol (FAO 1990) or Haplic Podzol (BGR 2007) with a high moisture status. The drained soil is acidic, occurring in the aluminium and iron buffer range (Ulrich 1983), usually with limited exchangeable base cations (Table 1). Thus, nutrition status is quite poor. Due to water logging in the few depressed areas, small acidic fens have developed; however, their extent is limited.

An old-growth mixed and multilayered forest of mainly Norway spruce and European beech covers about 10 ha in the reserve's core area (Fig. 1). In the 1940s, the forest was protected from logging; however, a forest map from 1909 (Carbonnier acc. to Brunet, pers. comm.) and studies by Niklasson et al. (2002) suggest that most probably the forest has remained mainly untouched for at least the past 100 years. Since 1995, 60 ha of previously managed Norway spruce adjoining the old-growth has become a buffer zone; accordingly the total reserve area accounts for 70 ha (Anonymous 2007).

A reconstruction of Siggaboda forest's development and fire regime during the last 1,000 years in the core plot (5 ha) by Niklasson et al. (2002) revealed that Pedunculate oak (Quercus robur L.) and Scots pine were abundant until the beginning of the nineteenth century and were then replaced by Norway spruce and European beech. The sudden end of previously frequent forest fires and the accompanying human disturbance 260 years ago led to the subsequent colonization of spruce. These factors are 
Table 1 Chemical soil properties of the organic layer and mineral soil of the root zone

\begin{tabular}{|c|c|c|c|c|c|c|}
\hline & $\mathrm{pH}\left(\mathrm{H}_{2} \mathrm{O}\right)$ & $\mathrm{pH}(\mathrm{KCL})$ & $\mathrm{C} / \mathrm{N}$ ratio & $\operatorname{CEC}\left(\mu\right.$ eq $\left.\mathrm{g}^{-1}\right)$ & $\begin{array}{l}\mathrm{Al}+\mathrm{Fe} \\
(\% \mathrm{CEC})\end{array}$ & $\begin{array}{l}\mathrm{K}+\mathrm{Ca}+\mathrm{Mg} \\
(\% \mathrm{CEC})\end{array}$ \\
\hline Organic layer: Of & 4.4 & 3.6 & 28.9 & - & - & - \\
\hline Organic layer: Oh & 3.8 & 3.0 & 30.9 & - & - & - \\
\hline Ahe $(\min$. soil $0-10 \mathrm{~cm})$ & 4.1 & 3.4 & 30.1 & 75.1 & 64.8 & 30.0 \\
\hline Bhs (min. soil $10-16 \mathrm{~cm}$ ) & 4.5 & 3.6 & 27.4 & 66.6 & 81.9 & 13.2 \\
\hline $\mathrm{Bv}-\mathrm{Cv}$ (min. soil $16-45 \mathrm{~cm}$ ) & 4.7 & 3.9 & - & 54.2 & 83.1 & 12.8 \\
\hline
\end{tabular}

Of, incompletely decomposed organic layer; Oh, humified organic layer containing amorphous organic material; Ahe, humified and eluviated mineral top soil horizon; Bhs, humified and podsolic mineral soil horizon; Bv-Cv, cambic mineral soil horizon (AK Standortskartierung 1996); $\mathrm{CEC}$, effective cation exchange capacity; $\mathrm{Al}+\mathrm{Fe}$, exchangeable aluminium and iron ions; $\mathrm{K}+\mathrm{Ca}+\mathrm{Mg}$, sum of exchangeable base cations; and $n=$ six samples

Fig. 1 Map of Siggaboda nature reserve showing the location of reserve's core area, buffer zone and core plot area

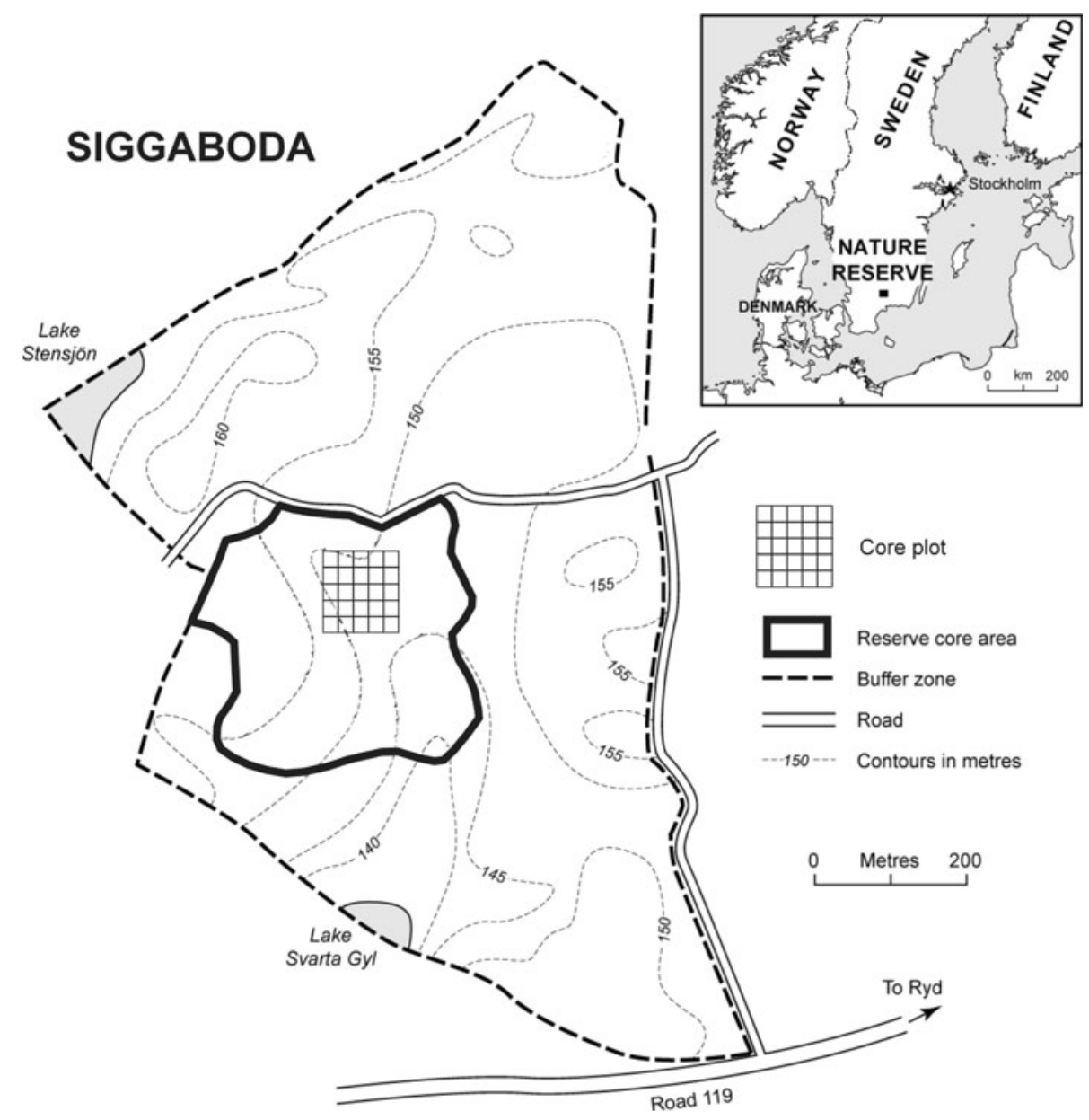

reputed to be main reasons for the loss of regeneration ability of pine and oak and thus forest succession.

At the time of study commencement in 2004, the uneven-age mixed forest in the centre of the core area (1 ha) was dominated by up to 144-year-old Norway spruce trees $(80 \%$ of the stand basal area). In contrast, several European beech individuals reached ages of more than 250 years, but they were less abundant (17\% of the stand basal area). Other tree species like Scots pine (Pinus sylvestris L.), Silver and Downy birch (Betula pendula Roth, B. pubescens Erh.), Mountain ash (Sorbus aucuparia L.) and Norway maple (Acer plataniodes L.) occurred rarely (3\% of stand basal area). Tree regeneration mainly of spruce and beech occurred on several parts of the core plot; however, it was patchy and unevenly spread. Herbaceous vegetation was sparse, with Vaccinium myrtillus and Oxalis acetosella as the dominant species. However, thick carpets of mainly feather mosses (Hylocomium splendens, 
Pleurozium schreberi) covered most of the mesic forest ground and the boulders. Peat mosses including Sphagnum spp. and Polytrichum spp. were observed, respectively, in fens and depressions with stagnant moisture.

On 8th/9th January 2005, hurricane 'Gudrun' hit southern Sweden with a wind velocity reaching up to $42 \mathrm{~m} \mathrm{~s}^{-1}$ (measured at Hanö, Blekinge region). In a small region, including Halland and southern and central Småland, around 75 million cubic metres of wood was uprooted or damaged on 160,000 ha of forest land (SMHI 2005). The Siggaboda reserve was in the region with high storm pressure (wind velocity: $32.5-35 \mathrm{~m} \mathrm{~s}^{-1}$, Fig. 2), where forest damage was often severe. The salvage cuttings and forest rehabilitation measures that followed in the Halland region were accompanied with a mid-summer drought (precipitation was 28 and $58 \mathrm{~mm}$ below average for June and July, respectively) and a heat wave $\left(1.4-4.5^{\circ} \mathrm{C}\right.$ above mean temperatures) in the following year 2006 (Fig. 3). There was an extraordinarily warm start to the 2007 growing season (March to May: $1.3-4.8^{\circ} \mathrm{C}$ above mean temperatures), with several spruce trees at Siggaboda reserve being attacked by bark beetles (Ips typographus), resulting in considerable die-off of emergent spruce trees.

\section{Measurements}

For stand structure recordings, we selected a quadratic 1 ha core plot $(100 \mathrm{~m} \times 100 \mathrm{~m})$ in the centre of the semi-natural old-growth forest and subdivided the plot using a $20 \mathrm{~m}$-grid (cf. procedure for German forest nature reserves, Meyer et al. 2001). The selected forest area was a typical section of the old-growth stand. In total 36 grid points of the core plot were leveled with an ultrasonic hypsometer (Vertex III, Haglöf Inc. Sweden) and a compass (PM-5/ 400PC, Suunto Inc., Finland) and subsequently permanently marked with wooden stakes.

Over the entire 1 ha core plot, in December 2004, we recorded each tree with a $d b h$ (tree diameter at $1.3 \mathrm{~m}$ above the ground) of $7 \mathrm{~cm}$ and larger. For each tree, we recorded species, cardinal location coordinates of the stem using above mentioned equipment and $d b h$ with a girth tape. Subsequently, a tagging system (Signumat, Latschenbacher, Austria) was used for temporarily (between 2004 and 2007) marking and numbering each tree measured. In addition, tree crown base height (CBH), crown mid height (CMH, where maximum crown width occurs) and tree top height $(\mathrm{TH})$ were measured in a central subsample of nine grid cells (0.36 ha). In early May 2005, before beech flushing, we mapped each tree's crown cover as the vertical projection of the outermost limits of the branch spread, determining coordinates from eight orthogonal projected crown edge points (cf. Frech et al. 2003). Additionally, all wind-thrown trees of the 'Gudrun' storm event were recorded with their windthrow direction (polar angle in gon) and distance between stem centre and the most distant tree parts. The last recording campaign in June 2007 included an assessment of the health status of all trees within the core plot; identifying dead and dying trees affected by insect attacks.

For tree coring, 29 beech and 23 spruce trees were selected in total. Of them, $73 \%$ were dominant and codominant and $27 \%$ were intermediate or suppressed. The study trees were cored at the end of August 2006 twice in opposite directions at a height of $1.3 \mathrm{~m}$. The increment cores were mounted on wooden boards, sanded, polished and visually cross-dated. Then, the width of every tree ring was measured at a precision of $1 / 100 \mathrm{~mm}$ using a LINTAB positioning table.

\section{Data analysis}

All recorded data were first organized in one relational database running on the open source database system PostgreSQL. For statistical analyses, we used the software package Statistica 7 (StatSoft Inc. 2005). Spatial analyses were partly performed with GIS (ArcGis 9, ESRI Inc.).
Fig. 2 Mean wind velocity $\left(\mathrm{m} \mathrm{s}^{-1}\right)$ on 8 th/9th January 2005 (left) and mean wood volume losses $\left(\mathrm{m}^{3} \mathrm{ha}^{-1}\right)$ (right) due to 'Gudrun' storm, location of Siggaboda nature reserve (SMHI 2005, modified)
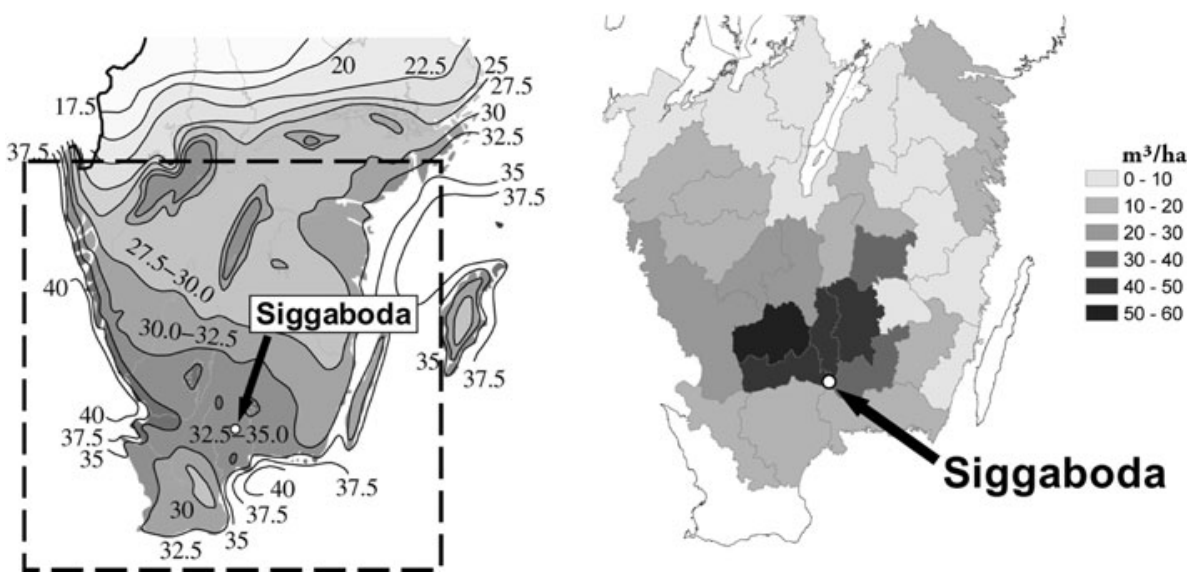
Fig. 3 Deviation of monthly means of air temperature (above) and precipitation (below) from long-term mean (1961-1990) at Växjö station
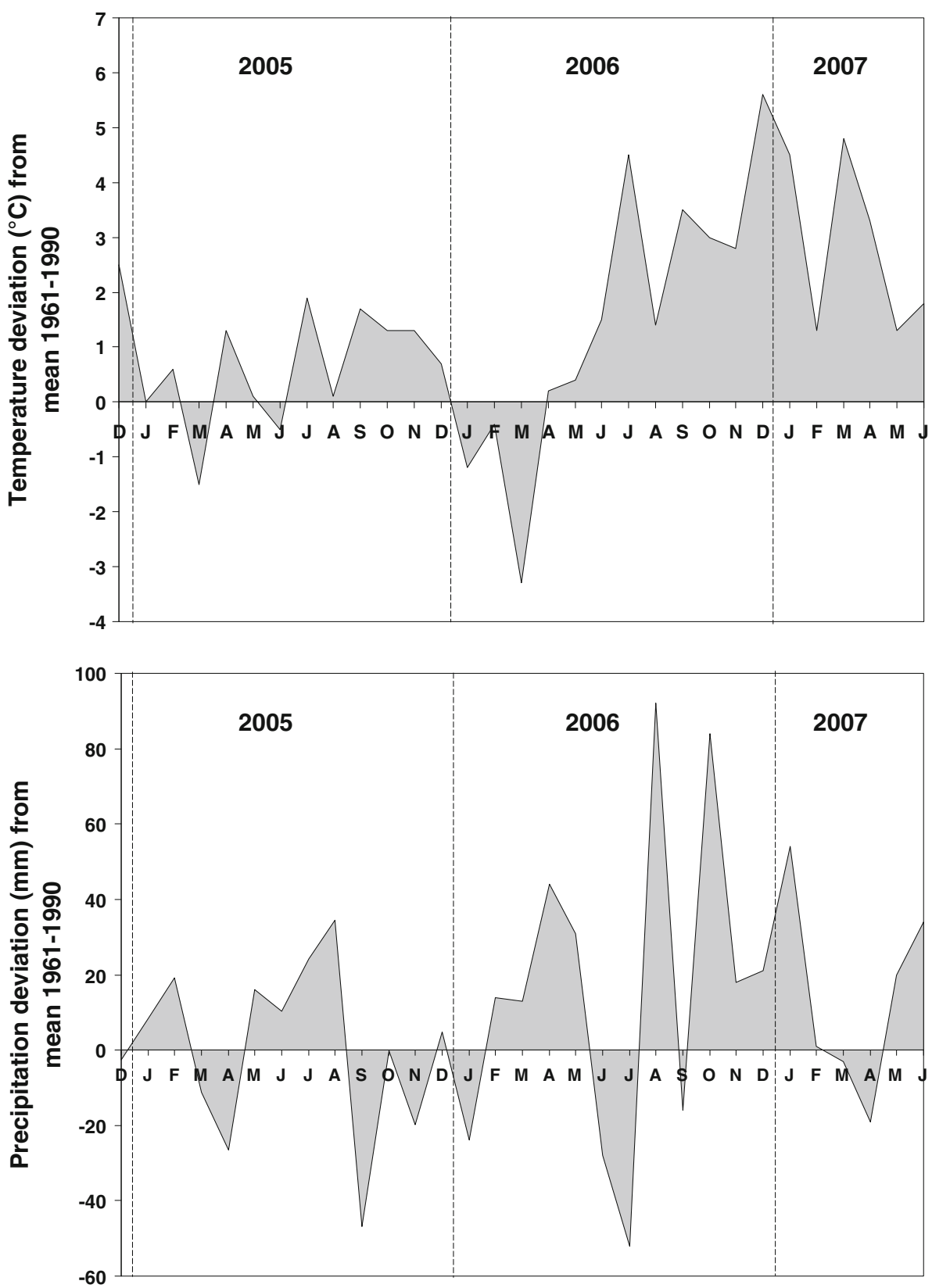

For the estimation of non-measured height data from measured $d b h$ data, we established a stand height curve using a Petterson function (Petterson 1955, Eq. 1; Fig. 5).

$h=1.3+\left(\frac{d b h}{a_{0}+a_{1} \cdot d b h}\right)^{3}$

where $h=$ tree height; $d b h=$ diameter at breast height $(1.3 \mathrm{~m})$ and $a_{0}, a_{1}=$ empirical parameter. Missing crown dimension data of the core plot trees outside the central subsample area were derived from diameter and height data using following function (Pretzsch and Kahn 1998, Eq. 2):
$\mathrm{CW}_{i}=\mathrm{e}^{a_{0}+a_{1} \ln \cdot d b h_{i}+a_{2} \cdot h+a_{3} \cdot \ln \frac{h_{i}}{d b h_{i}}}$

where $\mathrm{CW}=$ crown width,$d b h=$ diameter at breast height $(1.3 \mathrm{~m}) ; h=$ tree height and $a_{0}, \ldots, a_{3}=$ empirical parameter.

The model fits were achieved by a non-linear regression analysis considering the tree height and crown width residuals (cf. Pretzsch 2001). Fitting criterion was minimal quadratic variation and maximal coefficient of determination $\left(r^{2}\right)$.

For stand structure analyses and visualisation, we used the stand simulator BWIN-Pro 7 (Nagel et al. 2006) that is 
based on TreeGrOSS (Tree Growth Open Source Software, Nagel 2005).

Horizontal tree distribution patterns were analysed with the aggregation index of Clark und Evans (1954, Eq. 5). This method relates the mean $\left(\bar{r}_{a}\right.$, Eq. 3$)$ of observed treenearest neighbour distances $\left(r_{i}\right.$, Eq. 3$)$ to the predicted mean $\left(\bar{r}_{e}\right.$, Eq. 4) according to a random horizontal tree distribution (Poisson distribution):

$\bar{r}_{a}=\frac{1}{n} \sum_{i=1}^{n} r_{i}$

where $n=$ tree number,

$\bar{r}_{e}=\frac{1}{2 \sqrt{p}}$

where $p=$ tree density (tree number per area),

$R=\frac{\bar{r}_{a}}{\bar{r}_{e}}$

where $R=$ Index of Clark and Evans; $R<1$ : clustered distribution tendency, $R=1$ : random distribution and $R>1$ : dispersed distribution tendency.

Inter-tree competition was quantified with the competition index CI (Pretzsch and Schütze 2005, 2009, Eq. 6). Reference trees' competitors were identified by a virtual reverse cone approach (Pukkala and Kolström 1987; Biging and Dobbertin 1992; Pretzsch 1995): the axis of the reverse cone and tree axis were overlaid, and the cone's axis was placed in the tree crown. We used a $60^{\circ}$-vertex angle and defined $60 \%$ of tree height as basis height. All competitors' tree tops were situated within the virtual cone.

$\mathrm{CI}_{i}=\sum_{j=1}^{n} \beta_{j} \cdot \frac{\mathrm{CCA}_{j}}{\mathrm{CCA}_{i}} \cdot \mathrm{TMj}$

where $\mathrm{CI}_{i}=$ competition index for the reference tree $i$, $\beta_{j}=$ angle between cone vertex and competitor's $(j)$ tree top, $\mathrm{CCA}_{j}, \mathrm{CCA}_{i}=$ crown sectional area of competitors $(j)$ and reference tree $(i), \mathrm{TM}_{j}=$ species-specific light transmission coefficient for competitor tree $(j)$ (TM for European beech $=1.0$, Norway spruce $=0.8), n=$ number of competitors $(j)$ to reference tree $(i)$.

CI considers both tree-competitor distances and tree dimension differences in terms of height and crown extension between reference tree and competitors. The novel application of a species-specific transmission index allows a differentiated assessment of crown competition of either European beech or Norway spruce in the mixed stand.

Significant variation of wind-throw direction was assessed by comparing our recordings after 'Gudrun' hurricane with a chi-square probability distribution using STATISTICA (StatSoft Inc. 2005).
Tree ring width data were analysed using TSAP software (Rinntech, Heidelberg); mean series were established and statistically checked by using the program COFECHA (Holmes 1983). Pointer years have been determined when the tree-ring width deviated by $40 \%$ from the long-term trend, using a 13-year moving average (Cropper 1979; Bonn 1998; Neuwirth et al. 2007). For the climate analyses, a two-step-standardisation method was conducted by applying linear regressions and cubic smoothing splines to the mean series. For standardisation and index calculation, the software ARSTAN (Holmes et al. 1986) was used. Correlations between the tree-ring width series and the climate variables temperature and precipitation were calculated with the software DENDROCLIM2002 (Biondi and Waikul 2004).

\section{Results}

Stand structure

The comparison of stand characteristics before (December 2004) and after the 'Gudrun' storm (May 2005) as well as after drought and biotic impacts had occurred (June 2007), gives insight into both abiotic and biotic effects on the forest development (Fig. 4; Table 2).

At the study's commencement in 2004, the spruce trees had, in comparison to the beech trees, higher height and diameter means and contributed much more to the stand's basal area (spruce: $80 \%$, beech: 17\%) and growing stock (spruce: $86 \%$, beech: $12 \%$, Table 2). Spruce dominance is also visible in the stand height curves of both main species: spruces attained with a $d b h$ of $40 \mathrm{~cm}$ a height of approximately 28 metres on average, whereas beech trees of the same diameter were six metres shorter (Fig. 5).

The frequency distribution in height and diameter classes had two separate peaks for Norway spruce (Fig. 6). Emergent vertical elements of the first tree layer were singular tall spruce trees with a top height over $30 \mathrm{~m}$ that accounted for $18 \%$ of the total spruce tree number. Spruce dominated also the first tree layer between 20 and $27 \mathrm{~m}$ height that included about $37 \%$ of spruce trees. About $45 \%$ of the spruces are part of a second, subordinate tree layer with height up to $20 \mathrm{~m}$ (Fig. 6, left). The diameter frequency distribution had a corresponding two-peak-pattern with a first peak at $12 \mathrm{~cm}$ and a second at the $48 \mathrm{~cm}$ class. Singular emergent spruces reached diameters up to $88 \mathrm{~cm}$ (Fig. 6, right).

European beech height and diameter distributions differed from those of spruce, remaining mainly in the secondary tree layer, and thus behaving as a subordinate tree species. About $80 \%$ of the beech assemblage had tree heights up to $15 \mathrm{~m}$ and were part of the understorey and 

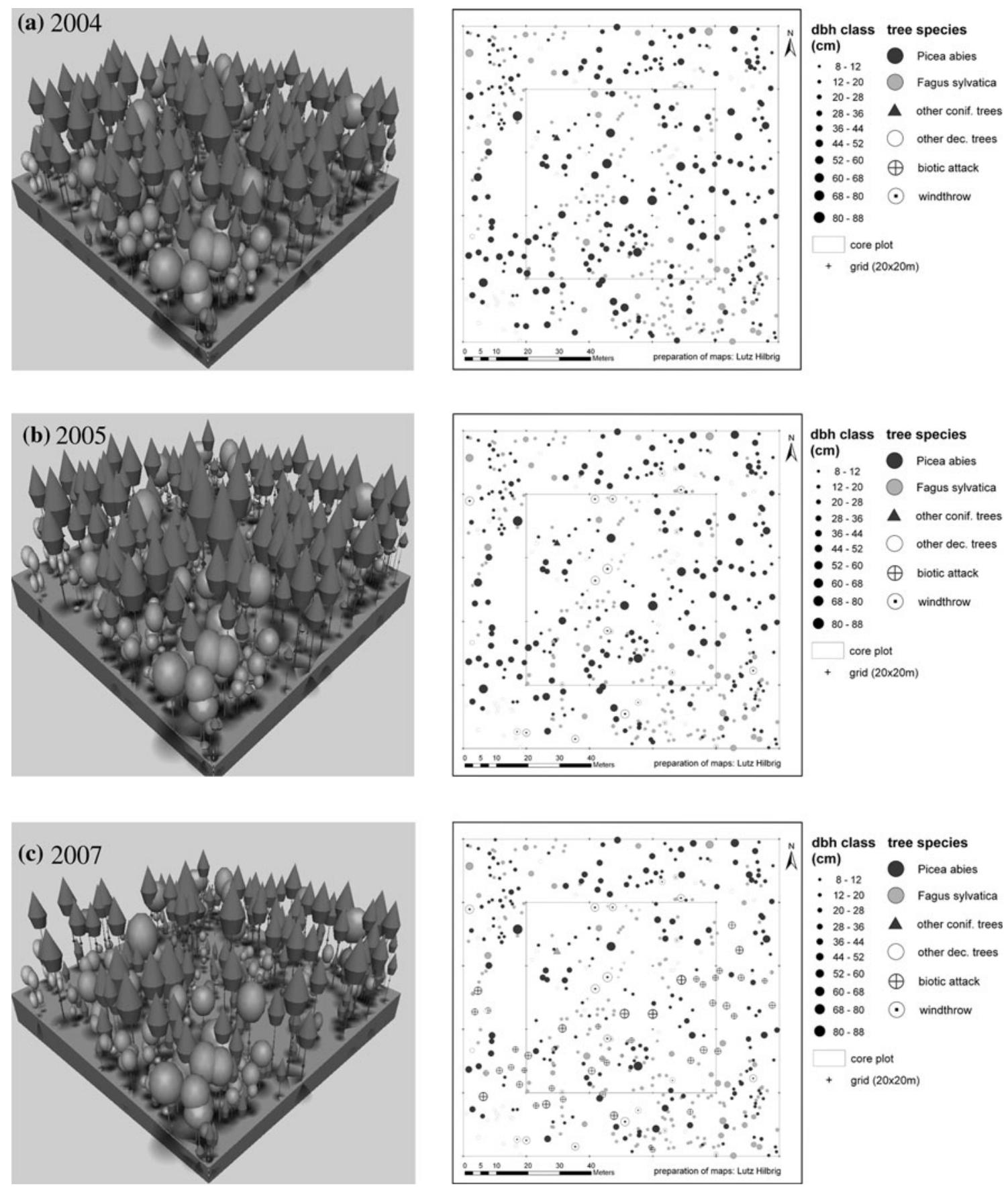

Fig. 4 Mixed stand structure dynamics: a December 2004, b May 2005 and c June 2007. Left stand visualization with BWIN-Pro 7.0 (remaining living trees only); right map of tree $(d b h \geq 7 \mathrm{~cm})$ position (incl. living tree removals); shown are tree removals due to 2005

intermediate tree layer. Only $20 \%$ of the beech trees attained $15-25 \mathrm{~m}$ tree height and were able to grow partly into the first tree layer. Correspondingly, beech was the most abundant in the lower diameter classes from 8 to $24 \mathrm{~cm}$, and frequency decreased steeply towards higher diameter classes showing a classic reverse J-shaped curve (Fig. 6). In contrast to beech, we did not find for spruce any
Gudrun storm (b, right) or due to Gudrun storm, drought and biotic attack impacts (c,right). Diameter and height increment in 2005 and 2006 growing season are not considered

clear relationship between tree dimension and tree age; beech individuals aged from 45 to 250 years.

Examining the stand's horizontal structure in December 2004, spruce and beech were intermixed on almost the entire core plot area. Some pure spruce groupings were found in the mid-West of the plot in a moist depression, whilst Downy birch was dominant in a fen at the southern- 
Table 2 Structural dynamics of the spruce-beech stand from December 2004 to June 2007

Mean values from all trees within the core plot ( $1 \mathrm{ha})$; height means are partially calculated from a stand height curve (Fig. 4) derived from a 0.36 ha-subsample; $d b h$ is the diameter at breast height $(1.3 \mathrm{~m}$ above ground). Tree increment from December 2004 to June 2007 is not included

\begin{tabular}{llllll}
\hline Species & $\begin{array}{l}\text { Mean } d b h \\
\mathrm{dg}(\mathrm{cm})\end{array}$ & $\begin{array}{l}\text { Mean height } \\
\text { hg }(\mathrm{m})\end{array}$ & $\begin{array}{l}\text { Tree number } \\
\left(n \mathrm{ha}^{-1}\right)\end{array}$ & $\begin{array}{l}\text { Basal area } \\
\left(\mathrm{m}^{2} \mathrm{ha}^{-1}\right)\end{array}$ & $\begin{array}{l}\text { Growing stock } \\
\left(\mathrm{m}^{3} \mathrm{ha}^{-1}\right)\end{array}$ \\
\hline
\end{tabular}

December 2004 before 'Gudrun' storm

$\begin{array}{lllrrr}\text { Spruce } & 35.8 & 28.0 & 263 & 26.5 & 347.0 \\ \text { Beech } & 19.9 & 16.4 & 182 & 5.7 & 48.4 \\ \text { Other species } & 20.8 & 16.1 & 40 & 0.8 & 6.7 \\ & & \text { Sum } & 485 & 33.0 & 402.1\end{array}$

Removals December 2004 to May 2005 due to 'Gudrun' storm

$\begin{array}{lrrrrr}\text { Spruce } & 45.2 & 31.3 & 19 & 3.0 & 42.5 \\ \text { Beech } & 23.3 & 17.9 & 10 & 0.4 & 3.4 \\ \text { Other species } & 11.2 & 10.9 & 3 & <0.1 & 0.2 \\ & & \text { Sum } & 32 & 3.5 & 46.1\end{array}$

May 2005 after 'Gudrun' storm

$\begin{array}{lrrrrr}\text { Spruce } & 35.0 & 27.7 & 244 & 23.6 & 304.5 \\ \text { Beech } & 19.7 & 16.3 & 172 & 5.2 & 45.0 \\ \text { Other species } & 20.9 & 16.2 & 37 & 0.8 & 6.5 \\ & & \text { Sum } & 453 & 29.6 & 356.0\end{array}$

Removals May 2005 to June 2007 due to 2006 drought and 2007 insect attacks

$\begin{array}{lrrrrr}\text { Spruce } & 50.2 & 32.6 & 46 & 9.1 & 126 . \\ \text { Beech + others } & 10.4 & 10.2 & 2 & <0.1 & 0.1 \\ & & \text { Sum } & 48 & 9.2 & 126.2\end{array}$

June 2007 after storm. drought and biotic impacts

$\begin{array}{lrrrrr}\text { Spruce } & 30.4 & 25.6 & 198 & 14.4 & 178.4 \\ \text { Beech } & 19.8 & 16.4 & 170 & 5.2 & 44.9 \\ \text { Other species } & 20.9 & 16.2 & 37 & 0.8 & 6.5 \\ & & \text { Sum } & 405 & 20.4 & 229.8\end{array}$

eastern edge (Fig. 4a). Mixed spruce and beech vary in their aggregation according to the Clarke Evans index $R$. We found a random spruce stem distribution $(R: 1.02, Z$ Score: $0.6, P>0.1$ ), whereas beech individuals showed a significant clustered horizontal stem distribution $(R: 0.83, Z$ Score: $-4.53, P<0.01)$.

Disturbance impacts

The 'Gudrun' storm in January 2005 had no significant impact on the mixed structure of the living elements of the stand (Table 2). All together, 32 living trees per hectare were uprooted or damaged. Of them, 19 were spruces and 10 were beeches. This accounted for only $7 \%$ of living trees. The mean heights and diameters of both species did not alter significantly. The same was found for basal area and growing stock. The storm threw trees in nearly all diameter classes (cf. Hilbrig and Bolte 2006); a peak at predominant and dominant height classes was not apparent. Nearly half of the trees lost, including all of the fallen beeches, were not primarily thrown or broken by the storm, but rather by secondary damage caused by neighbouring wind-thrown or wind-broken trees (Fig. 4b). Recorded tree failures of spruce and beech trees showed a significant 

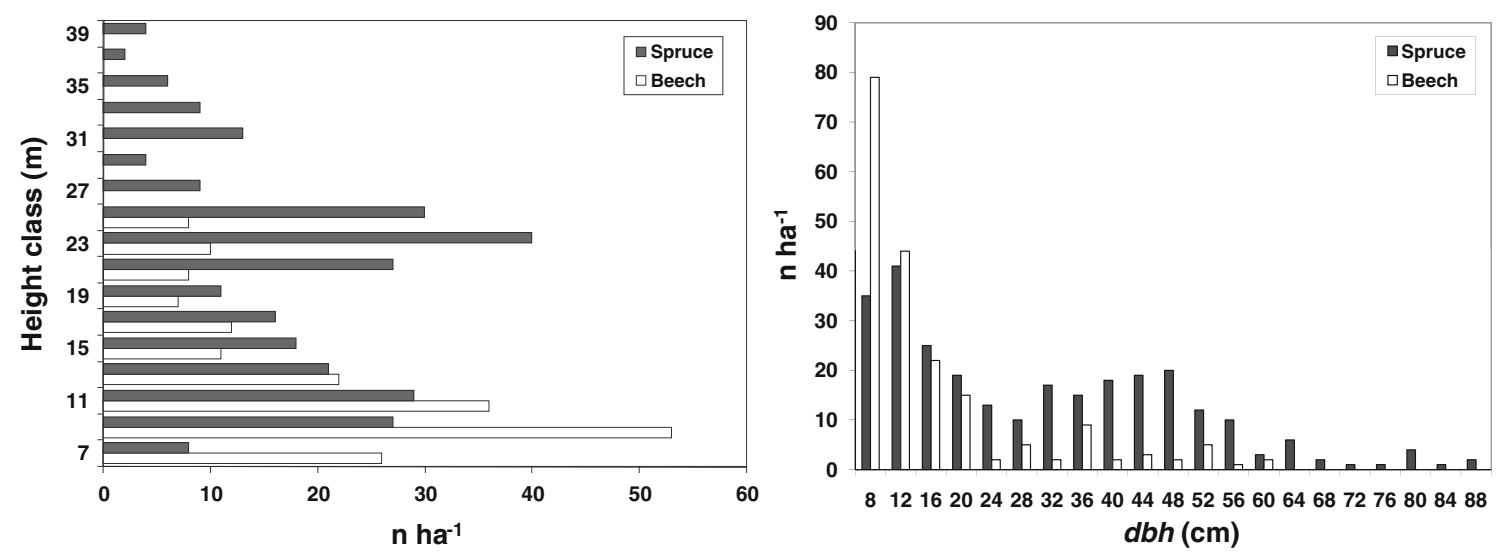

Fig. 6 Frequency distribution of Norway spruce and European beech in 2004 considering tree height (left, 2 m-height classes) and dbh (right, $4 \mathrm{~cm}-d b h$ classes); only living trees included

clustered distribution (Clark Evans $R: 0.83, Z$ Score: -4.53, $P<0.01$; Hilbrig and Bolte 2006).

Analyses on wind-throw direction included both living and standing dead trees that were thrown (Fig. 7). Wind throw and breakage direction was mainly towards the East (NE, SE: 0-200 gon), with $70 \%$ of the living and standing dead trees thrown in this direction $(n=41)$, with the highest scores in the NE classes (0-100 gon). Westerly directions (NW, SW: 200-400 gon) accounted for 30\% $(n=18)$ with a decrease in damaged tree number from South-West to North-West direction. Between the main directions East and West, we found a significant deviation from equal distribution of class frequencies $\left(\chi^{2}=8.97\right.$, $P<0.01)$.

The widespread tree damage recorded in June 2007 revealed a considerable increase in tree failure following

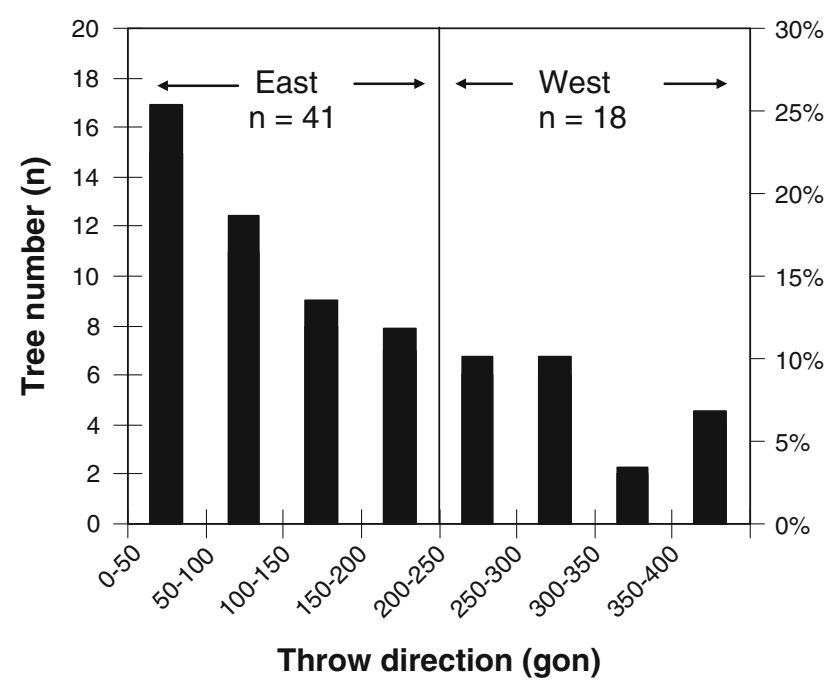

Fig. 7 Results of the wind-throw analyses: wind-throw directions (50 gon classes), frequency distribution between main directions East and West is not equal (chi-square test, $\chi^{2}=8.97, P<0.01$ ) the mid-summer drought 2006 and the bark beetle infestation (Ips typographus) in spring 2007 (Fig. 4c). However, only spruces were affected. In total, about $19 \%$ of spruce trees and $41 \%$ of the standing volumes were lost of the remaining living stand after the 'Gudrun' hurricane (Table 2; Fig. 8). The trees lost were mainly the emergent and dominant spruce trees from the first tree layers (Fig. 8), changing the mixed stand structure. Large canopy gaps were opened over mainly beech understorey in a belt from South-East to mid-West of the core plot (Fig. 4c). Competition intensity, defined as combined competition pressure of all competitors to a subject tree, decreased by ca. $40 \%$ for both Norway spruce and European beech (using the mean CI competition index, Pretzsch and Schütze 2005). The CI decreased from 2004 to 2007 for beech from 2.8 to 1.7 and for spruce from 2.7 to 1.6 , respectively.

Combined effects of all abiotic and biotic disturbance impacts have clearly changed growing stock partitioning among living and dead spruce stand parts, whereas European beech remained nearly unaffected (Table 2; Fig. 8). For spruce, all recorded tree failures had a random distribution pattern (Clark Evans R: 0.9, Z Score: -1.47). The storm led to both modest wind-throw of living spruces and wind-breakage of standing dead spruce stems, whereas bark beetles attacks increased the amount of standing dead wood volume. This resulted in a dominance of dead wood volume over the wood volume of living trees. European beech raised its contribution of wood volume of the living stand from $12 \%$ in 2004 to $20 \%$ in 2007 . Spruce contribution to stand growing stock decreased from 86 to $78 \%$.

Long-term radial increment

Apart from the specific and short-term effects of climatic induced disturbances considered, the comparison of longterm radial increment of beech and spruce using 

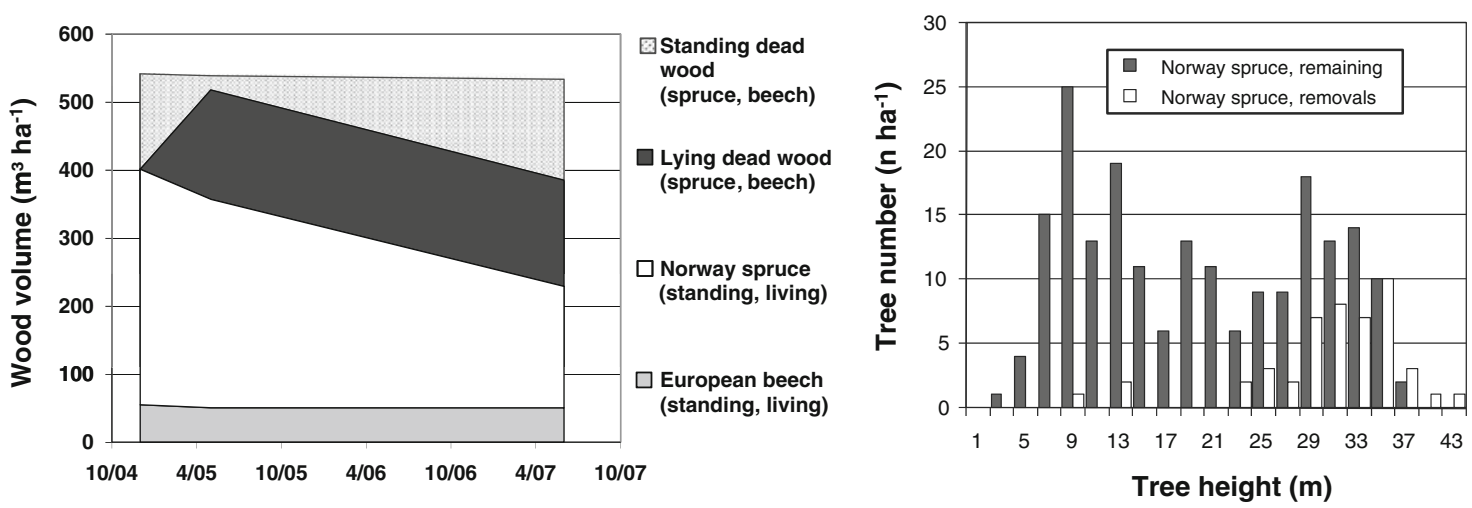

Fig. 8 Growing stock variation from December 2004 to June 2007 due to all abiotic and biotic impacts (left); number of remaining spruce trees and removals due to disturbance from December 2004 to June 2007 (right)

dendroecological methods revealed the markedly higher increment of the spruce trees during the observation period from 1894 to 2006 (Fig. 9).

However, since 1976 (which was characterised by an extremely dry summer in southern Sweden, Lehner and Döll 2001), the radial growth of spruce trees shows a clear decrease. In contrast, beech growth hardly seems to be affected. Its radial growth trend is nearly constant and apparently slightly increases (Table 3). Comparing two periods of the same length (1894-1949; 1950-2005), it becomes obvious that the dominance of spruce increment decreases over the last 50 years.

\section{Discussion}

Vegetation dynamics in the past

The old-growth stand in the core area of Siggaboda reserve represents a unique example for a (semi-)natural Norway spruce-European beech forest. The site has been the forest continuously for more than 2,000 years (Björkman and Bradshaw 1996), a refuge for the fire-sensitive beech during previous disturbances and seems to not have been

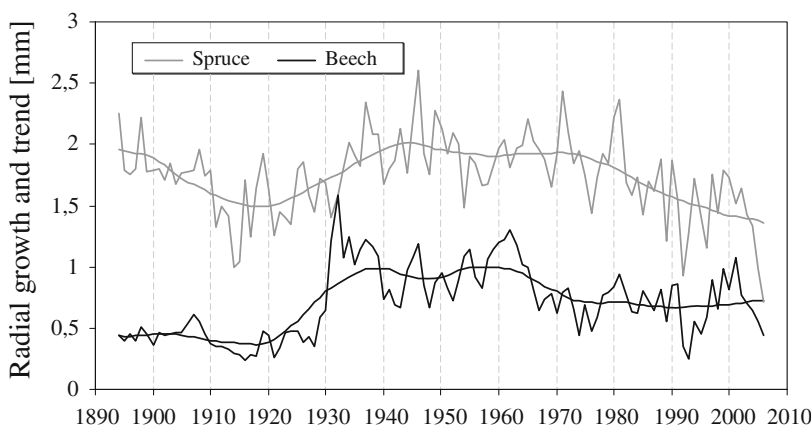

Fig. 9 Radial growth and trend of European beech and Norway spruce for the period from 1894 to 2006
Table 3 Diameter increment in \% of the long-term mean 1894-2005, and the increment ratio of spruce/beech in $\%$ of the period means

\begin{tabular}{lcc}
\hline Periods & $1894-1949$ & $1950-2005$ \\
\hline Diameter increment beech & 88.1 & 111.7 \\
Diameter increment spruce & 100.7 & 99.3 \\
Increment ratio spruce/beech & 282.4 & 219.6 \\
\hline
\end{tabular}

affected by humans for at least 100 years (Niklasson et al. 2002). In the boreo-nemoral zone of southern Scandinavia, the natural distribution ranges of Norway spruce and European beech overlap at the northern distribution margin of the beech (Lindqvist 1959; Meusel et al. 1965; Björkman 1999).

At the Siggaboda core plot, the distinct differences of horizontal stem distribution of Norway spruce (with an apparently random pattern) and European beech (with a clustered distribution) (Fig. 4a) are obviously induced by the varying establishment history of the two tree species. European beech and Norway spruce colonised southern Sweden recently compared to the other native tree species (Bradshaw et al. 2000): beech between the years 500 and 1650 A.D.-Siggaboda was reached between 1000 and 1100 A.D. - and spruce from 1550 to 1750 A.D., the latter date also applicable for establishment at Siggaboda (Björkman and Bradshaw 1996; Björkman 1996a; Lindbladh et al. 2007). There is some evidence that beech establishment in southern Sweden at the stand scale was mainly not driven by climate variation after the last glacial period. Rather, human activities seem to have facilitated the spreading of beech leading to a patchy, discontinuous expansion front with earlier occurrence at sites affected by human activities that had created semi-open forest structures (Björkman 1996b; Bradshaw and Lindbladh 2005). However, this theory contradicts previous ideas established in Central Europe that beech post-glacial expansion was mainly due to climate warming (Firbas 1949; Ellenberg 
1988; Tinner and Lotter 2006). Following the human impact theory, human-induced forest fire regimes at Siggaboda starting from the year A.D. 1000 onwards may have brought the precondition needed for beech invasion. However, in later times, forest fire prevented the greater expansion and dominance of fire-sensitive beech and restricted beech occurrence to refuges (Niklasson et al. 2002). This idea fits to our findings that beech occurs even today on the major boulder ridges in the North-East and South-West of the core plot which should be less affected by forest fires (Fig. 4a). But what kept European beech from significant expansion from its refuges when forest fire ceased suddenly on mid of eighteen century? It is probable that this was mainly due to the rapid expansion of the very competitive spruce from the north, with spruce spreading over the entire core plot area in just 50 years (Björkman and Bradshaw 1996) and causing the decline of Quercus in the area (Niklasson et al. 2002).

In 2004 (before 'Gudrun'), the diameter frequency distribution of partly spread European beech exhibited in principle a reverse J-shaped curve (Fig. 6) that was also reported for some but not all virgin beech forests in Southeastern Europe (Meyer et al. 2003; Westphal et al. 2006). Linder et al. (1997) found similar distribution values also for Norway spruce in central and northern Sweden. Reverse J-shape diameter distribution is reputed to indicate structural stability of an uneven-aged forest (Sterba 2004) with a high density of understorey tree individuals representing candidates for replacing overstorey trees after disturbances. In this respect, beech potential exceeded that of Norway spruce.

\section{Competitive interactions between European beech and Norway spruce}

At Siggaboda Reserve, the performance ability of European beech is lower than Norway spruce (Table 2; Figs. 5, $6,9)$. This is obvious in the Norway spruce/European beech ratio before 'Gudrun', which was 1.4 for tree number, but 4.6 for basal area and 7.2 for the standing volume on the core plot. Diameter increment of Norway spruce was more than two times higher than that of European beech (Table 3), showing an unbalanced productivity of the two competing species as found for Norway spruce-European beech mixtures in Germany (Kennel 1965). At the northern margin of its distribution range, European beech growth is limited by short growing seasons with quite low mean air temperatures, extended frost periods and cold winter temperatures. According to a compilation of its minimum requirements (Bolte et al. 2007), beech needs a January long-term air temperature mean above $-3^{\circ} \mathrm{C}$ (Köppen 1888; Hueck 1936), less than 141 frost days with a daily minimum temperature under $0^{\circ} \mathrm{C}$, and more than 217 days with a daily mean of at least $7^{\circ} \mathrm{C}$ (Hjelmqvist 1940; Tarasiuk 1999). At Siggaboda, European beech has reached almost its minimum requirements with mean air temperature (1961-1990) $-2.8^{\circ} \mathrm{C}$ in both January and February measured at nearby Växjö climate station. Moreover, frost periods often last from November to March, reaching the reputed constraints for length of growing season. Thus, beech performance may be limited by climate as well as by the competitive pressure of the boreal tree species, Norway spruce, which is well adapted to climate conditions such as those found at Siggaboda (e.g. Schmidt-Vogt 1987) and hence competitively superior to beech in the overstorey.

In the understorey and intermediate tree layer of the stand (height $<20 \mathrm{~m}$ ), spruce competitive superiority is less clear, since individuals of both beech and spruce showed similar tree height for the same $d b h$. The average tree age of the spruce overstorey and understorey differed by more than 70 years, suggesting that growth conditions varied between individuals of both layers. Compared to younger spruce growing under spruce-beech canopy, older dominating spruce individuals may have grown up under a less dense canopy of previously more abundant, but less competitive Scots pine and oak species (Niklasson et al. 2002). The distinct differences in height/diameter ratio $(h / d)$ with lower values for older spruce and higher ones for young spruce support this idea (Hilbrig and Bolte 2006). Due to carbon allocation hierarchy (Waring 1987), diameter growth falls behind height growth when assimilate production is limited by competition (Van Hees 1997; Collet et al. 2002; Ammer et al. 2005; Czajkowski et al. 2005).

In terms of its competition strategy, beech is well adapted to the asymmetric competition with Norway spruce found aboveground due its greater efficiency in the occupation of canopy space (Pretzsch and Schütze 2005) and its exceptional plasticity in biomass partitioning and carbon allocation (Bolte et al. 2004). The latter can lead to vertical stratification in the Norway spruce and beech fine root systems (Rothe 1997; Schmid 2002), also was identified in part at Siggaboda (Kampf, pers. comm.), and results in 'competitive reduction' (Kelty 1992), particularly for beech (cf. Pretzsch and Schütze 2009). Therefore, the competition belowground of a Norway spruce-beech overstorey probably is more balanced than that aboveground. This fact is reputedly indicative of the long-term competitive success of beech in mixed stands (Büttner and Leuschner 1994; Schmid 2002).

Disturbance impacts

Although 'Gudrun' caused disastrous damage and timber losses in southern Sweden, in many Norway spruce plantations in particular, which reflected the storm damage after 'Anatol' in western Denmark and southern Sweden in 1999 
(Bradshaw et al. 2000), the old-growth Norway sprucebeech forest remarkably was little affected (Table 2; Fig. 4b). When considering the few spruce trees that were thrown over all height classes, the varying microsite conditions, which determine root system anchorage, seemed to be a more important factor for wind-throw risk than tree dimension traits above ground, like tree height (e.g. König 1995; Niklas 2002; Schelhaas et al. 2007), crown length or width (Röhrig et al. 2006) and $h / d$ ratio (Cremer et al. 1982). On the one hand, the high rigidity and mass of the soil-root plate of trees (Coutts 1986) found in the predominately boulder-rich areas of the core plot increased the uprooting resistance of shallow-rooting spruce with top heights up to $40 \mathrm{~m}$ and more (cf. Blackwell et al. 1990). On the other hand, much lower spruces of 20-25 m tree height were thrown on stagnic and peat soils that constrain root development and provide low soil rigidity (Nicoll et al. 2008). Prevailing throw direction towards East with the majority of throws towards North-East (Fig. 7) matches the main south-westerly wind direction during the storm maximum (33 $\mathrm{m} \mathrm{s}^{-1}$ at Vaxjö, 08/01/05, 7-9 p.m. SMHI 2005). Nilsson et al. (2007) identified from storm analyses based on the 'Anatol' storm in 1999 a threshold of $30 \mathrm{~m} \mathrm{~s}^{-1}$ for critical wind speed that was exceeded only for about two hours (SMHI 2005). Recent wind simulation of the model-system WINDA using regionally downscaled climate change scenarios (Blennow and Olofsson 2008) exhibits a high future probability of exceeding critical wind speed from south-westerly directions at Växjö region.

The presence of European beech in the stand mixture had no considerable positive effect on the stability of neighbouring spruce trees, as was found for mixed spruce-beech stands during the 'Lothar' storm (Schütz et al. 2006). However, this difference may be due to the fact that the secondary beech layer did not provide support and shelter for first spruce layer, and thus did not increase the collective wind stability (e.g. Mitscherlich 1974; Schelhaas et al. 2007). We observed secondary damages to understorey tree caused by fallen or broken overstorey trees that shattered entire plants, bent over, or broke branches from smaller or younger residuals in the surrounding area, leading to a clustered horizontal damage distribution. This damage type, representing half of the tree and all beech losses during the storm event, is similar to logging damage during uneven management (Nyland 1989) and constituted a remarkably large portion of the damage to the otherwise minor storm damages at the Siggaboda core plot.

In contrast to the 'Gudrun' storm in 2005, the midsummer drought and bark beetle attack from 2006 to 2007 had considerable impacts on stand structure and growing stock allocation between living and dead stand components, due to the loss of several dominating spruce individuals (Table 2; Figs. 4c, 8). Schlyter et al. (2006) illustrated for spruce in northern Europe the interacting effects of biotic agents and climate change (including both climatic extremes and long-term changes): abiotic impacts of climate change (like drought) lower the vitality of spruce and increase its susceptibility to biotic attacks, e.g. by spruce bark beetle. Drought is in particular a problem for shallow-rooting spruce (Puhe 2003), and root competition with beech may further decrease rooting depth (Schmid 2002; Bolte and Villanueva 2006). Possible root breakage due to the 'Gudrun' storm may have additionally raised spruce sensitiveness to drought in the following years, when the emergent spruce trees, with large upper crowns and heavily transpiring leaf areas (cf. Herzog et al. 1998), needed a continuous and sufficient soil water resource supply.

Bark beetle infestation on a catastrophic level following storm damage was observed after the 1969 storms in southern Sweden (Nilsson et al. 2004). Since swarming activity of spruce bark beetle (Ips typographus) in southern Sweden is temperature controlled (Jönsson et al. 2007), the warm growing seasons 2006 and 2007 (Fig. 3) provided good conditions for the spread of bark beetles at Siggaboda reserve. Salvage cutting was not allowed on the entire 75 ha area of the reserve, and thrown spruce stems remained as good brooding material for bark beetles (Schlyter et al. 2006). Thus, a combination of probable vitality decrease in the most dominant spruces and optimal infestation conditions for spruce bark beetle populations led to the remarkably high loss of old spruce individuals.

Finally, the combination of disturbances observed, including wind-throw, drought and bark beetle attack, changed the forest structure mainly by the losses of dominant spruce individuals. This supports prevalent ideas of an increasing abiotic and biotic risk for spruce in southern Sweden due to climate change (e.g. Jönsson et al. 2009). Distinct decrease in canopy closure and vertical competition favours the growth of the tree understorey and the intermediate tree layer where beech is over-represented compared to spruce. This indicates that European beech will be at an advantage in the future compared to spruce, with more frequent and intensive disturbances induced by drought, storm and biotic agents having negative consequences for spruce's dominance. These findings are in keeping with a study of long-term disturbances in a Danish semi-natural, deciduous forest, where, given its abundance, storm damage was found to favour beech more than other deciduous tree species (Wolf et al. 2004). This result points to a future increase in the importance of beech for forestry in southern Scandinavia.

The long-term success of beech under disturbance regimes may be based on its regeneration recruitment and survival potential under low light conditions (Ellenberg 
1988), and its ability to survive disturbances and impede similar-sized competitors (Pretzsch and Schütze 2009).

Long-term warming effects

In addition to a disturbance regime driven by climate extremes, long-term warming is changing growth relations between Norway spruce and European beech. Due to the position in the intermediate tree layer and the relatively short growing season, the radial growth of the beech trees is consistently smaller than the spruce's. A decrease and an increase in the increment of young trees of both species were observed in the periods from 1900 to 1920 and from 1920 to 1940 , respectively. The remarkable growth increase in both Norway spruce and beech in latter period indicates a lower competition pressure, perhaps due to natural or anthropogenic disturbances and gap dynamics. Niklasson et al. (2002) found indications of a final, lowintensity logging towards the end of the nineteenth century probably to establish and favour a new tree generation, which may have encompassed some individuals cored in this study. However, since the 1940s, there seems to be direct growth competition after canopy closure between the species: whilst the growth trend of one species increases, the other's decreases (Fig. 9). Since the 1970s, more precisely since the drought year 1976 when there was an exceptionally dry summer in southern Sweden (Lehner and Döll 2001), the growth trend of the spruce trees decreases constantly, whereas the beech growth seems unaffected or even slightly increases (Table 3).

The climate-growth analysis also revealed the increased correlation between beech growth and summer droughts over the last 50 years. In contrast, the sensitivity of spruce growth to summer droughts could be observed since approximately the 1950s (Eckstein and Krause 1989; Neumann 2001; Piovesan et al. 2003; Wilmking et al. 2005; Dobbertin and Giuggiola 2006). The future warming might therefore prove favourable for growth of European beech compared to Norway spruce.

\section{Conclusions}

Both disturbance studies and long-term growth analyses point to a future loss of Norway spruce's competitive superiority over European beech due to climate change, at the northern margin of beech's distribution range. Compared to beech, spruce appears to be more sensitive to interacting abiotic and biotic impacts like storm, drought and bark beetle attacks, all believed to increase considerably with future climate change in southern Scandinavia. Recent warming has already favoured the long-term growth of beech relative to spruce. In particular, the expected climate change-induced damage to the emergent and overstorey spruces may further promote competitive ability of beech compared with spruce. Disturbances due to short to medium term weather extremes have to be regarded as key processes for both a future expansion of European beech range and a future narrowing of Norway spruce range in Scandinavia towards the north. Thus, southern Sweden may be regarded in the future as the southern margin of Norway spruce distribution rather than as northern margin area of European beech range (cf. Grundmann 2009).

Acknowledgments This study was funded by the German Research Foundation (Deutsche Forschungsgemeinschaft, DFG: RO 910/10, BO 1906/3), the Thure Rignells Foundation (Tranemåla Erik och Ebba Larssons samt Thure Rignells Stiftelse, Bengt Ljungström) and was conducted in co-operation with the Broadleaf Program (Ädellövprogrammet) of the Swedish University of Agricultural Science (SLU), Southern Swedish Forest Research Centre at Alnarp (Coordinator: Prof. Dr. Magnus Löf). We are grateful to all supporters and collaborators. Dr. Tomasz Czajkowski (vTI Eberswalde), Heiko Rubbert, Dr. Thomas Kompa, Frauke Koch, René Grippert (Göttingen University) and Dr. Lars Droessler (SLU Alnarp) supported us in field work, Ian Rayner (vTI Eberswalde) improved the present manuscript, and Dr. Gina Hannon (Liverpool University) provided us with the Siggaboda map (Fig. 1). We thank all for the outstanding assistance.

Open Access This article is distributed under the terms of the Creative Commons Attribution Noncommercial License which permits any noncommercial use, distribution, and reproduction in any medium, provided the original author(s) and source are credited.

\section{References}

Ammer Ch, Ziegler C, Knoke T (2005) Zur Beurteilung von intraund interspezifischer Konkurrenz von Laubbaumbeständen im Dickungsstadium. Allg Forst- u Jagdztg 176:85-94

Anonymous (2007) Naturreservat i Kronobergs län: Siggaboda. Faktablad Länsstyrelsen i Kronobergs län. Available: http://www.lans styrelsen.se/NR/rdonlyres/A3DECC04-2C28-40DF-B16D-BB964 2676D6C/109358/siggaboda_582253770.pdf. Accessed 20 Jan 2009

BGR [Bundesanstalt für Geowissenschaften und Rohstoffe] (2007) World reference base for soil resources 2006 (German edition). 1st update. BGR, Hannover

Biging GS, Dobbertin M (1992) A comparison of distance-dependent competition measures for height and basal area growth on individual conifer trees. For Sci 38(3):695-720

Biondi F, Waikul K (2004) DENDROCLIM2002: a C++ program for statistical calibration of climate signals in tree-ring chronologies. Comput Geosci 30:303-311

Björkman L (1996a) Long-term population dynamics of Fagus sylvatica at the northern limits of its distribution in southern Sweden: a paleoecological study. The Holocene 6:225-234

Björkman L (1996b) The late Holocene history of beech Fagus sylvatica and Norway spruce Picea abies at stand scale in southern Sweden. Lundqua Thesis 39, Lund University, Lund

Björkman L (1999) The establishment of Fagus sylvatica at the standscale in southern Sweden. The Holocene 9(2):237-245

Björkman L, Bradshaw R (1996) The immigration of Fagus sylvatica L. and Picea abies (L.) Karst. into a natural forest stand in 
southern Sweden during the last 2000 years. J Biogeogr 23:235244

Blackwell PG, Rennolls K, Coutts MP (1990) A root anchorage model for shallowly rooted Sitka spruce. Forestry 63:73-91

Blennow K, Olofsson E (2008) The probability of wind damage in forestry under a changed wind climate. Clim Change 87:347-360

Bolte A, Villanueva I (2006) Interspecific competition impacts on the morphology and distribution of fine roots in European beech (Fagus sylvatica L.) and Norway spruce (Picea abies (L.) Karst.). Eur J Forest Res 125(1):15-26

Bolte A, Rahmann T, Kuhr M, Pogoda P, Murach D, Von Gadow K (2004) Relationships between tree dimension and coarse root biomass in mixed stands of European beech (Fagus sylvatica L.) and Norway spruce (Picea abies [L.] Karst.). Plant Soil 264(1-2):1-11

Bolte A, Czajkowski T, Kompa T (2007) The north-eastern distribution range of European beech-a review. Forestry 80(4):413429

Bolte A, Ammer C, Löf M, Nabuurs GJ, Schall P, Spathelf P (2009) Adaptive forest management - a prerequisite of sustainable forestry in the face of climate change. In: Spathelf $P$ (ed) Sustainable forest management in a changing world: European perspective. Springer, Heidelberg, pp 115-139

Bonn S (1998) Dendroecological investigations of competition dynamics in mixed beechoak stands and its modifications expected due to climatic changes. Contributions to Forest Sciences Tharandt 3, Technical University, Dresden

Bradshaw RHW, Lindbladh M (2005) Regional spread and standscale establishment of Fagus sylvatica and Picea abies in Scandinavia. Ecology 86(7):1679-1686

Bradshaw RHW, Holmqvist BH, Cowling SA, Sykes MT (2000) The effects of climate change on the distribution and management of Picea abies in southern Scandinavia. Can J For Res 30:19921998

Büttner V, Leuschner C (1994) Spatial and temporal patterns of fine root abundance in a mixed oak beech forest. For Ecol Manage 70:11-21

Christensen JH, Christensen OB (2007) A summary of the PRUDENCE model projections of changes in European climate by the end of this century. Clim Change 81(Suppl. 1):7-30

Christensen JH, Hewitson B, Busuioc A, Chen A, Gao X, Held I, Jones R, Kolli RK et al (2007) Regional climate projections. In: Solomon SD, Chen Z, Marquis M, Averyt KB, Tignor M, Miller HL (eds) Climate change 2007: the physical science basis. Contribution of Working Group I to the 4th assessment report of the Intergovernmental Panel on Climate Change. Cambridge University Press, Cambridge

Clark PhJ, Evans FC (1954) Distance to nearest neighbor as a measure of spatial relationships in populations. Ecology 35(4):445-453

Collet C, Lanter O, Pardos M (2002) Effects of canopy opening on the morphology and anatomy of naturally regenerated beech seedlings. Trees 16:291-298

Coutts MP (1986) Components of tree stability in Sitka spruce on peaty gley soil. Forestry 59:173-197

Cremer KW, Borough CJ, McKinnel FH, Carter PR (1982) Effects of stocking and thinning on wind damage in plantations. NZ J For Sci 12:244-266

Cropper JP (1979) Tree-ring skeleton plotting by computer. TreeRing Bulletin 39:47-59

Czajkowski T, Kühling M, Bolte A (2005) Einfluss der Sommertrockenheit im Jahre 2003 auf das Wachstum von Naturverjüngungen der Buche (Fagus sylvatica L.) im nordöstlichen Mitteleuropa. Allg Forst- u Jagdztg 176:133-143

Dale VH, Joyce LA, McNulty S, Neilson RP, Ayres MP, Flannigan MD, Hanson PJ, Irland LC, Lugo AE, Peterson CJ, Simberloff
D, Swanson FJ, Stocks BJ, Wotton BM (2001) Climate change and forest disturbances. Bioscience 51:723-734

Dobbertin M, DeVries W (2008) Interactions between climate change and forest ecosystems. In: Fischer R (ed) Forest ecosystems in a changing environment: identifying future monitoring and research needs. Report and Recommendations COST Strategic Workshop 11-13 March 2008 Istanbul, Turkey. http://www. costforest2008.org/docs/COST-Brochure.pdf. Accessed 15 July 2008

Dobbertin M, Giuggiola A (2006) Baumwachstum und erhöhte Temperaturen. Forum für Wissen, Wald und Klimawandel, pp $35-45$

Eckstein D, Krause C (1989) Dendroecological studies on spruce tress to monitor environmental changes around Hamburg. IAWA Bulletin 10(2): 175-182

Ellenberg H (1988) Vegetation ecology of central Europe. Cambridge University Press, Cambridge

FAO [Food and Agriculture Organization] (1990) Guidelines for soil description, 3rd edn (Revised). FAO, Rome

Firbas F (1949) Spät- und nacheiszeitliche Waldgeschicjte Mitteleuropas nördlich der Alpen, vol 1. G. Fischer, Jena

Frech A, Leuschner C, Hagemeyer M, Hölscher D (2003) Nachbarschaftsbezogene Analyse der Kronenraumbesetzung von Esche, Hainbuche und Winterlinde in einem artenreichen Laubmischwald (Nationalpark Hainich, Thüringen). Forstwiss Cbl 122:22-35

Fuhrer J, Beniston M, Fischlin A, Frei Ch, Goyette S, Jasper K, Pfister Ch (2006) Climate risks and their impact on agriculture and forests in Switzerland. Clim Change 79:79-102

Giesecke T, Hickler T, Kunkel T, Sykes MT, Bradshaw RHW (2007) Towards an understanding of the Holocene distribution of Fagus sylvatica L. J Biogeogr 34:118-131

Grundmann BM (2009) Dendroklimatologische und dendroökologische Untersuchungen des Zuwachsverhaltens von Buche und Fichte in naturnahen Mischwäldern. Dissertation, Technische Universität Dresden, Dresden

Herzog KM, Thum R, Kronfuss G, Heldstab HJ, Hasler R (1998) Patterns and mechanisms of transpiration in a large subalpine Norway spruce (Picea abies (L.) Karst.). Ecol Res 13(2):105112

Hilbrig L, Bolte A (2006) Wirkung des Orkans "Gudrun" auf die Bestandesstruktur eines Fichten-Buchen-Naturwaldes in Südschweden. Beiträge zur Jahrestagung der Sektion Waldbau im DFFV vom 18.09. bis 19.09.2006 in Tharandt, Technische Universität Dresden, Tharandt, pp 87-97

Hjelmqvist H (1940) Studien über die Abhängigkeit der Baumgrenzen von der Temperaturverhältnissen unter besonderer Berücksichtigung der Buche und ihrer Klimarassen. Blom, Lund

Holmes RL (1983) Computer-assisted quality control in tree-ring dating and measurement. Tree-Ring Bulletin 43:69-78

Holmes RL, Adams RK, Fritts HC (1986) Tree-ring chronologies of western North America: California, eastern Oregon and northern Great Basin with procedures used in the chronology development work including users manuals for computer programs COFECHA and ARSTAN, Chronology Series VI. Laboratory of Tree-Ring Research, Universitiy of Arizona, Tuscon

Hueck K (1936) Pflanzengeographie Deutschlands. Berlin-Lichterfelde, Bermühler

Jönsson AM, Harding S, Bärring L, Ravn HP (2007) Impact of climate change on the population dynamics of Ips typographus in southern Sweden. Agr For Met 146:70-81

Jönsson AM, Appelberg G, Harding S, Barring L (2009) Spatiotemporal impact of climate change on the activity and voltinism of the spruce bark beetle, Ips typographus. Glob Change Biol 15(2):486-499 
Kelty MJ (1992) Comparative productivity of monocultures and mixed-species stands. In: Kelty MJ, Larson BC, Oliver CD (eds) The ecology and silviculture of mixed-species forests. Kluwer, Dordrecht, pp 125-141

Kennel R (1965) Untersuchungen über die Leistung von Fichte und Buche im Rein- und Mischbestand. Allg Forst-u Jagdztg 136(149-161):173-189

König A (1995) Sturmgefährdung von Beständen im Altersklassenwald. J.D. Sauerländer's, Frankfurt/M

Köppen FP (1888) Geographische Verbreitung der Holzgewächse des europäischen Russlands und des Kaukasus. Kaiserl. Akadem. Wissenschaften, St. Petersburg

Leckebusch GC, Ulbrich U (2004) On the relationship between cyclones and extreme windstorm events over Europe under climate change. Global Planet Change 44:181-193

Leckebusch GC, Koffi B, Ulbrich U, Pinto JG, Spangehl T, Zacharias S (2006) Analysis of frequency and intensity of European winter storm events from a multi-model perspective, at synoptic and regional scales. Clim Res 31:59-74

Lehner B, Döll P (2001) Europe's drought today and in the future. In: Lehner B, Henrichs T, Döll P, Alcamo J (eds) EuroWassermodel-based assessment of European water resources and hydrology in the face of global change:7.1-7.16. Available http://www. usf.uni-kassel.de/cesr/index.php?option=com_content\&task=view $\&$ id $=134 \&$ Itemid $=72$. Accessed 9 July 2009

Leuschner C, Meier IC, Hertel D (2006) On the niche breadth of Fagus sylvatica: soil nutrient status in 50 Central European beech stands on a broad range of bedrock types. Ann For Sci 63:335-368

Lindbladh M, Brunet J, Hannon G, Niklasson M, Eliasson P, Eriksson G, Ekstrand A (2007) Forest history as a basis for ecosystem restoration-a multidisciplinary case study in a South Swedish temperate landscape. Rest Ecol 15(2):284-295

Linder P, Elfving B, Zackrisson O (1997) Stand structure and successional trends in virgin boreal forest reserves in Sweden. For Ecol Manage 98:17-33

Lindqvist B (1959) Forest vegetation belts in southern Scandinavia. Acta Hortii Gotoburgensis 22:111-144

Meusel H, Jäger E, Weinert T (1965) Vergleichende Chorologie der zentraleuropäischen Flora. Karten, G. Fischer, Jena

Meyer P, Ackermann J, Balcar P, Boddenberg J, Detsch R, Förster B, Fuchs H, Hoffmann B, Keitel W, Kölbel M, Köthke C, Koss H, Unkrig W, Weber J, Willig J (2001) Untersuchung der Waldstruktur und ihrer Dynamik in Naturwaldreservaten. IHW, Eching

Meyer P, Tabaku V, Lüpke BV (2003) Die Struktur albanischer Rotbuchen-Urwälder-Ableitungen für eine naturnahe Buchenwirtschaft. Forstw Cbl 122:47-58

Mitscherlich G (1974) Sturmgefahr und Sturmsicherheit. Schweiz. Zeitschr Forstwes 125:199-216

Nagel J (2005) TreeGrOSS - eine Java basierte Softwarekomponente zur Waldwachstumsmodellierung für Forschung. Lehre und Praxis. DVFFA-Sektion Forstliche Biometrie und Informatik, 15. Tagung Freiburg 9-10. Oktober 2003, pp 33-37

Nagel J, Duda H, Hansen J (2006) Forest Simulator BWINPro7. Forst und Holz 61:427-429

Neumann U (2001) Relationships between weather and increment courses of spruce stands in eastern Erzgebirge Mountains. Contrib For Sci Tharandt 11:1-193

Neuwirth B, Schweingruber F, Winiger M (2007) Spatial patterns of central European pointer years from 1901 to 1971. Dendrochronologia 24:79-89

Nicoll BC, Gardiner BA, Peace AJ (2008) Improvements in anchorage provided by the acclimation of forest trees to wind stress. Forestry 81:389-398

Niklas KJ (2002) Wind, size and tree safety. J Arboricult 28(2):84-93
Niklasson M, Lindbladh M, Björkman L (2002) A long-term record of Quercus decline, logging and fires in a southern Swedish FagusPicea forest. J Veg Sci 13:765-774

Nilsson SG, Arup U, Baranowski R, Ekman S (1995) Lichens and beetles as indicators in conservation forests. Conserv Biol 9:1208-1215

Nilsson C, Stjernquist I, Bärring L, Schlyter P, Jönsson AM, Samuelsson H (2004) Recorded storm damages in Swedish forests 1901-2000. For Ecol Manage 199:165-173

Nilsson C, Goyette S, Bäring L (2007) Relating forest damage data to the wind field from high-resolution RCM simulations: Case study of Anatol striking Sweden in December 1999. Global Planet Change 57:161-176

Nyland RD (1989) Logging Damage. In: Clark FB, Hutchinson JG (eds) Central Hardwood Notes, Note 8.02. U.S. Department of Agriculture, Forest Service, North Central Forest Experiment Station, St. Paul, MN

Petterson H (1955) Die Massenproduktion des Nadelwaldes. Mitt. Der Forstl. Forsch.-Anst. Schwedens 45, 1B: 392-580

Piovesan G, Bernabei M, Di Filippo A, Romagnoli M, Schirone B (2003) A long-term tree ring beech chronology from a highelevation old-growth forest of Central Italy. Dendrochronologia 21(1):13-22

Pretzsch H (1995) Zum Einfluss des Baumverteilungsmusters auf den Bestandeszuwachs. Allg Forst- und Jadgztg 166:190-201

Pretzsch H (2001) Modellierung des Waldwachstums. Parey, Berlin

Pretzsch H, Kahn M (1998) Konzeption und Konstruktion des Wuchsmodells SILVA 2.2, Methodische Grundlagen. Abschlussber. Projekt W 28, Lehrstuhl für Waldwachstumskunde der Ludwig-Maximilians-Univ. München, Freising/Weihenstephan, part 2

Pretzsch H, Schütze G (2005) Crown allometry and growing space efficiency of Norway spruce (Picea abies (L.) Karst.) and European beech (Fagus sylvatica L.) in pure and mixed stands. Plant Biol 7:628-639

Pretzsch H, Schütze G (2009) Transgressive overyielding in mixed compared with pure stands of Norway spruce and European beech in Central Europe: evidence on stand level and explanation on individual tree level. Eur J Forest Res 128:183-204

Puhe J (2003) Growth and development of the root system of Norway spruce (Picea abies) in forest stands-a review. For Ecol Manage 175:253-273

Pukkala T, Kolström T (1987) Competition indices and prediction of radial growth in Scots pine. Silva Fennica 21(1):55-67

Raab B, Vedin H (eds) (1995) Climate, lakes and rivers. The National Atlas of Sweden. SNA, Stockholm

Röhrig E, Bartsch N, Lüpke BV (2006) Waldbau auf ökologischer Grundlage (begr. v. A. Dengler), 7th edn. E. Ulmer Verlag, Stuttgart

Rothe A (1997) Einfluss des Baumartenanteils auf Durchwurzelung, Wasserhaushalt, Stoffhaushalt und Zuwachsleitung eines Fichten-Buchen-Mischbestandes am Standort Höglwald. Forstl Forschungsber München 163:1-213

Schelhaas MJ, Nabuurs GJ, Schuck A (2003) Natural disturbances in the European forests in the 19th and 20th centuries. Global Change Biol 9:1620-1633

Schelhaas MJ, Kramer K, Peltola H, van der Werf DC, Wijdeven SMJ (2007) Introducing tree interactions in wand damage simulation. Ecol Model 2-4:197-209

Schlyter P, Stjernquist I, Bärring L, Jönsson AM, Nilsson C (2006) Assessment of the impacts of climate change and weather extremes on boreal forests in northern Europe, focusing on Norway spruce. Clim Res 31:75-84

Schmid I (2002) The influence of soil type and interspecific competition on the fine root system of Norway spruce and European beech. Basic Appl Ecol 3(4):339-355 
Schmidt-Vogt H (1987) Die Fichte : ein Handbuch in zwei Bänden Bd. 1: Taxonomie, Verbreitung, Morphologie, Ökologie, Waldgesellschaften, 2nd edn. Parey, Hamburg

Schütz JP, Gotz M, Schmid W, Mandallaz D (2006) Vulnerability of spruce (Picea abies) and beech (Fagus sylvatica) forest stands to storms and consequences for silviculture. Eur $\mathrm{J}$ For Res 125(3):291-302

Sjörs H (1999) The background: geology, climate and zonation. In: Rydin H, Snoeijs P, Diekmann M (eds) Swedish plant geography. Acta Phytogeogr Suec 84:5-14

SMHI [Sveriges Meteorologiska och Hydrologiska Institut] (2005) Januaristormen 2005. Faktablad nr. 25, SMHI, Nörrköping

StatSoft Inc. (2005) STATISTICA für Windows [Software-System für Datenanalyse] Version 7.1. www.statsoft.com

Sterba H (2004) Equilibrium curves and growth models to deal with forests in transition to uneven-aged structure-application in two sample stands. Silva Fennica 38(4):413-423

Tarasiuk S (1999) Buk zwyczajny (Fagus sylvatica L.) na obrzeżach zasięgu w Polsce. Fundacja Rozwój SGGW, Warszawa

Tinner W, Lotter AF (2006) Holocene expansion of Fagus sylvatica and Abies alba in Central Europe: where are we after eight decades of debate? Quat Sci Rev 25:526-549
Ulrich B (1983) Soil acidity and its relation to acid deposition. In: Ulrich B, Pakrath J (eds) Effects of accumulation of air pollutants in forest ecosystems. D Reidel Publ Comp Dordrecht, The Netherlands, pp 127-146

Van Hees AFM (1997) Growth and morphology of pedunculate oak (Quercus robur L.) and beech (Fagus sylvatica L.) seedlings in relation to shading and drought. Ann Sci For 54:9-18

Waring RH (1987) Characteristics of trees predisposed to die. Bioscience 37:569-574

Westphal C, Tremer N, von Oheimb G, Hansen J, von Gadow K, Härdtle W (2006) Is the reverse J-shaped diameter distribution universally applicable in European virgin beech forests? For Ecol Manage 223:75-83

Wilmking M, D’Arrigo R, Jacoby GC, Juday GP (2005) Increased temperature sensitivity and divergent growth trends in circumpolar boreal forests. Geophys Res Lett 32:L15715. doi: 10.1029/2005GLO23331

Wolf A, Møller PF, Bradshaw RHW, Bigler J (2004) Storm damage and long-term mortality in a semi-natural temperate deciduous forest. For Ecol Manage 188:197-210 